\title{
Can location value capture pay for transit? Organizational challenges of transforming theory into practice
}

\author{
Deborah Salon, Arizona State University, Tempe, AZ \\ Elliott Sclar, Columbia University, New York, NY \\ Richard Barone, Regional Plan Association, New York, NY
}

\begin{abstract}
Successful public transit systems increase the value of locations they serve. Capturing this location value to help fund transit is often sensible, but challenging. This article defines location value capture, and synthesizes lessons learned from six European and North American transit agencies that have experience with location value capture funding. The opportunities for and barriers to implementing location value capture fall into three categories: agency institutional authority, agency organizational mission, and public support for transit. When any of these factors is incompatible with a location value capture strategy, implementation becomes difficult. In four of the cases studied, dramatic institutional change was critical for success. In five cases, acute crisis was a catalyst for institutional change, value capture implementation, or both. Using value capture strategies to fund transit requires practitioners to both understand agency organizational constraints, and to view transit agencies as institutions that can transform in response to changing situations.
\end{abstract}

KEYWORDS: institutions; public finance; policy adoption

\section{INTRODUCTION}

Successful public transport systems ease access, increasing location value in both station areas and across their entire service regions. Improved access fosters the agglomeration economies that make cities vibrant economic engines. Location value capture is the concept that governments can capture part of this created agglomerative value, and use it to help support transit service.

Although the notion of leveraging agglomerative location value is obvious, it is not a key transit funding source outside of a few Asian cities. In an environment of increasingly constrained public resources, identifying ways to capture the value created by public investments is critical. This research addresses two related questions:

1. What are the challenges and opportunities faced by transit agencies that are implementing location-based funding strategies in a significant way in North American and European contexts?

2. What practical lessons can be drawn from the experiences of "leader" agencies that will allow others to take better advantage of location-based funding opportunities?

To answer these questions, we conducted in-depth case studies of transit funding in six European and North American cities with transit agencies that are leaders in implementing location value capture strategies: London, Paris, New York, Washington DC, Montreal, and San Francisco. This is not a random or representative sample of transit agencies, nor was it meant to 
be. We purposely chose major transit agencies that are widely viewed as leaders in the area of location value capture implementation with the goal of identifying common themes and lessons that might be transferable to others.

This study is distinct from most in the value capture literature because our unit of analysis is the transit agency rather than the specific value capture strategy or value capturefunded project. Thus, our main findings illuminate the role of transit agency institutional structure in either facilitating or obstructing an agency's use of location value capture funding.

We found that the opportunities for and barriers to implementation fall into three basic categories: agency institutional authority, agency mission, and public support for transit. When any of these factors is incompatible with location-based funding strategies, implementation becomes difficult. In particular, in four of the cases studied, significant implementation was made possible by recent and dramatic institutional change. In five of the cases, an acute funding or operational crisis was a catalyst for institutional change, location value capture implementation, or both. While the specific stories of these six cities and their transit agencies are not directly transferable to other contexts, the common threads in these stories suggest that some broad lessons may be generalizable.

We proceed by first defining location value capture and summarizing insights and findings from prior research on the related concept of land value capture. We then describe our research methodology and summarize the state of value capture use to fund transit in each of our case study cities. The main results follow, providing an account of location value capture implementation in each of six cases with special emphasis on the role of transit agency institutional characteristics. We conclude with a discussion of the lessons that can be learned from these cases and avenues for future research.

\section{LOCATION VALUE CAPTURE}

Work from the University of Minnesota (Lari et al. 2009; Iacono et al. 2009; Zhao et al. 2012) provides a framework for identifying the most efficient set of funding sources for transportation, based on the principle that costs paid should be proportional to benefits received. Extending this framework, we identify four sets of transit beneficiaries:

1. riders,

2. the general public of the state, province, or nation (the larger economy is enabled by cities, which are made more productive by transit),

3. the general public within the transit service area (the regional economy is enabled by transit), and

4. property and business owners near transit stations.

The first two beneficiaries help pay for transit through fares and general taxes, respectively.

It is the last two groups of non-user beneficiaries that experience sustained location-based value from transit upkeep and gain added benefits from the construction of new transit. This is value over and above that which they derive either as part of the larger general public or as riders. However, these beneficiaries often do not contribute to paying for the costs of the 
infrastructure or service in proportion to the benefit they receive. Location value capture mechanisms allow these location beneficiaries of transit to help pay for it.

Table 1: Location Value Capture Mechanisms

\begin{tabular}{|c|c|c|}
\hline $\begin{array}{l}\text { Location of } \\
\text { value }\end{array}$ & $\begin{array}{l}\text { Location Value } \\
\text { Capture Mechanism }\end{array}$ & Brief Definition \\
\hline \multirow{2}{*}{$\begin{array}{l}\text { Service } \\
\text { region }\end{array}$} & $\begin{array}{l}\text { Income or payroll- } \\
\text { based tax }\end{array}$ & $\begin{array}{l}\text { Income earners or employers in the transit system service area pay a tax } \\
\text { that funds the transit agency. }\end{array}$ \\
\hline & Motorist fees & Motorists contribute through tolls and parking payments. \\
\hline \multirow{2}{*}{$\begin{array}{l}\text { Station } \\
\text { district - } \\
\text { service } \\
\text { region }\end{array}$} & $\begin{array}{l}\text { Land value } \\
\text { tax/location benefit } \\
\text { levy }\end{array}$ & $\begin{array}{l}\text { Tax on the value of land in the vicinity of transit. Note that this } \\
\text { mechanism is a tax on the land only, distinct from a conventional } \\
\text { property tax. It is rarely used. }\end{array}$ \\
\hline & $\begin{array}{l}\text { Transit-focused } \\
\text { development fees }\end{array}$ & $\begin{array}{l}\text { Developers working in the vicinity of a transit system pay extra fees for } \\
\text { the privilege of building new real estate projects. }\end{array}$ \\
\hline \multirow{2}{*}{$\begin{array}{l}\text { Station } \\
\text { district }\end{array}$} & $\begin{array}{l}\text { Tax increment } \\
\text { financing (TIF) }\end{array}$ & $\begin{array}{l}\text { Any post-transit increase in total property tax revenues within the } \\
\text { designated TIF district funds the transit agency. Note that this mechanism } \\
\text { will capture the value of the transport improvement plus the value added } \\
\text { of any other changes to the local economy. }\end{array}$ \\
\hline & $\begin{array}{l}\text { Special assessment } \\
\text { districts or } \\
\text { Betterment fees }\end{array}$ & $\begin{array}{l}\text { Districts benefiting from a public transport improvement may choose to } \\
\text { self-impose a tax to help pay for the improvement. The group that pays } \\
\text { the tax could be local landowners, local residents, and/or local businesses. }\end{array}$ \\
\hline \multirow{4}{*}{$\begin{array}{l}\text { Station and } \\
\text { adjacent } \\
\text { property }\end{array}$} & Joint development & $\begin{array}{l}\text { Joint development is a partnership between the private sector and the } \\
\text { local government or public transport agency to build a real estate project } \\
\text { on land controlled by the public sector. The local government or public } \\
\text { transport agency captures value by requiring a private developer partner } \\
\text { to build a portion of the station amenity as part of their real estate project, } \\
\text { thereby reducing their capital costs. }\end{array}$ \\
\hline & Sale or lease of land & $\begin{array}{l}\text { The government or transit agency acquires land in and adjacent to a } \\
\text { planned transit facility at the pre-transit market price. After the system is } \\
\text { built, the owner can sell or lease the now higher-value land on the open } \\
\text { market, capturing the access value. }\end{array}$ \\
\hline & $\begin{array}{l}\text { Sale or lease of } \\
\text { development rights or } \\
\text { air rights }\end{array}$ & $\begin{array}{l}\text { The government or transit agency acquires land in and adjacent to a } \\
\text { planned transit facility at the pre-transit market price. After the system is } \\
\text { built (or concurrently), the owner can then enter into long-term leases } \\
\text { with developers for ground, air, or subsurface development rights. The } \\
\text { access value of transit is capitalized into the lease price. }\end{array}$ \\
\hline & $\begin{array}{l}\text { Leasing of } \\
\text { commercial space in } \\
\text { and around stations }\end{array}$ & $\begin{array}{l}\text { The transit agency or local government develops and retains ownership of } \\
\text { the commercial space in and around stations, and leases it out to } \\
\text { businesses at market prices. }\end{array}$ \\
\hline
\end{tabular}

The definition of location value capture proposed here is broader than that of land value capture found in the literature. The conventional approach to value capture, rooted in standard microeconomics, implicitly assumes that all added value is capitalized in land prices, hence land value taxation approaches alone capture the value created by transit. But this only holds true 
when the assumptions of perfect knowledge and Pareto Optimal land uses also hold. Thus the conventional approach is actually a special case. For an extended discussion of the underlying economic theory see Arnott and Stiglitz (1979).

Access-enhanced location value can manifest in a range of economic activities: to landowners through higher land values, to workers and employers through enhanced labor market access for both, to business through an expanded customer base, to drivers through both less need to drive and - in the special case of transit - less congested roads, to developers through higher sale prices for their developments, and to advertisers through more viewers of their advertisements. Governments are more likely to be successful in capturing this diffusion of value enhancement if they have the flexibility to use as many different tools as they have available to them. Evidence in the literature as well as our case studies supports this idea. Hence the location value capture mechanisms we consider go beyond explicit land value.

Table 1 provides brief definitions of mechanisms along the continuum of location value capture funding sources for transit, from location value that is specific to being physically adjacent to a station to that stemming from the boost transit gives to the regional economy. This list is not exhaustive; capturing the value of location and access is a task that cities, regions, and transit agencies must approach with creativity.

\section{How much location value does transit generate?}

A clear prerequisite to implementing location value capture funding strategies is that captureable value exists. Many studies estimate the relationship between transit presence and nearby property values. The created location value is conceived as a function of service type (i.e., bus, rail), distance between property location and station or stop, property use (i.e., residential, commercial), service quality, and available transportation alternatives. Reviews and meta-analyses of this literature report a generally positive relationship between transit and property values, with the largest relationships found for rail transit (RICS 2002; Smith and Gehring 2006; Debrezion et al. 2007; Salon and Shewmake 2011; Mohammad et al. 2013).

For two of our study areas, researchers estimated the total value added attributable to a particular transit line. Dubé et al. (2013) estimated that one commuter rail line in Montreal generated $\$ 1.2$ billion in residential property value. A study of the Crossrail in London projected the new line to generate an additional $£ 5.5$ billion in both commercial and residential property value (GVA 2012).

Additional work aims to estimate the total costs and benefits of transit systems. In her study of the regional rail system in Philadelphia, Pack (1992) put together estimates of the value of vehicle external costs avoided, welfare gains for transit riders, and capitalization of transit proximity into property values. She found that the net benefits outweigh government subsidies by a comfortable margin. A study of public transit in Montreal estimated that public transit generated more than $\$ 1.6$ billion in benefits in 2003 (BTMM 2004). Finally, the Washington Metropolitan Area Transit Authority compared the social costs of the current transit system to one without transit in the region, finding that the benefits of the presence of transit to the region 
are in the billions of dollars annually (WMATA 2011). These studies highlight the fact that public transit generates location-based value in multiple sectors of the economy.

\section{When location value capture makes sense}

There is consensus among scholars that using location value capture strategies to fund part of the cost of infrastructure and operation makes sense under three conditions: (1) location value is created, (2) the spatial "benefit zone" is well-defined, and (3) beneficiaries have the resources to contribute (e.g. Arnott and Stiglitz 1979; Ingram and Hong 2012; Peterson 2009).

The most prominent case of a group receiving benefits but not necessarily able to pay is the case of homeowners whose property values increase. Because enhanced asset value does not generate realizable income for homeowners unless they sell or refinance, increasing residential property taxes meets substantial political opposition. Because commercial rents rise and fall more easily in line with expected business revenues, this issue is not as important for commercial properties.

This raises an important equity concern when considering strong reliance on locationbased strategies to pay for transit. If agencies prioritize projects that can more easily generate value to capture, lower income populations that rely on transit may be left out of investment plans.

Further, it is worth noting that it is not necessarily desirable for the public authority to capture all of the location-based benefit of transit. It is in the interest of both the transit agency and the city to leave some windfall value on the table to incentivize developers to construct higher density development near transit. In Paris - one of our case study areas - the newspaper Le Monde criticized a recent plan for attempting to capture so much of the value that it might depress development (Jérôme 2014).

\section{Revenue stream adequacy, stability, and responsibility}

One large difference between location value capture funding and most general public revenue-based transit funding is the potential for revenue stream volatility. Location value capture mechanisms tied to specific real estate markets fluctuate with the rhythms of those markets. Mechanisms tied to the asset value of new development yield revenue streams that rise and fall with market volatility. Similarly, location value capture mechanisms tied to payroll are subject to business cycle fluctuations. Overall public sector budgets will also rise and fall with economic cycles, but these fluctuations are often not as large as those in individual economic sectors (Cornia and Nelson, 2010).

Our case study research uncovered specific examples of this political-economic challenge in London, New York, and Paris when location-based revenues fell short of expectations. In this situation, an important equity question is who picks up the funding slack, given the political reality that market lows and highs are likely unbalanced with respect to location-based revenues. When revenues are higher than expected - for instance during a construction boom - there may be a call to reduce the tax rate. When revenues are lower than expected, however, this usually 
means that there is an economic slowdown, and raising rates to cover the shortfall in this context is neither likely nor advisable.

\section{Paying for construction versus operations}

It is easiest to gain public support for location value capture strategies if the captured funds are slated to be used to construct new infrastructure. This is understandable; when infrastructure is first built, the location value changes the most. Indeed, a recent set of value capture examples published by the American Public Transit Association included only one case in which location beneficiaries funded ongoing operating costs (APTA 2015).

It is perhaps reasonable to argue that the station area location beneficiaries of transit should shoulder a relatively large portion of the initial construction costs, and a much smaller portion of the ongoing maintenance and operating costs. From the initial construction, these beneficiaries reap large gains in the value of their locations. These large gains stem from both the access benefits from the transit service itself as well as the benefits from knock-on neighborhood development and revitalization that often occurs. The continuation of transit service preserves the access benefits, but, once neighborhood development occurs, transit service often has little relationship to that development.

As we illustrate in Table 1, however, some location value capture funding mechanisms are geographically more expansive, capturing value from entire service regions. The rationale is that the existence of a quality public transport system boosts the entire regional economy. These value capture funds are often used to pay for operations and maintenance of the existing system.

\section{PRIOR FINDINGS ON LAND VALUE CAPTURE IMPLEMENTATION CHALLENGES}

While the literature points to equity and revenue stability challenges in using land value capture to fund transit, its implicit message is that these strategies can be relatively easily implemented in an equitable and efficient manner. Hence they should be utilized often, but are not (USGAO 2010). A number of researchers have asked why, and we summarize their findings here. The existing literature enumerates six challenges to implementing value capture to fund transit.

First, public support is critical for implementation - especially from the location beneficiary group being asked to contribute. Based on a series of 17 case studies of land value capture projects, Mathur and Smith (2012) documented stakeholder support as a critical factor in the success of impact fees, special assessment districts, tax increment financing, and joint development. Rybeck (2004) documented the case of the New York Avenue red line Metro station in Washington DC, partly funded by a special assessment on local businesses - which was suggested by a consortium of the businesses themselves. In their 2010 report, the USGAO found evidence that support from private developers and/or property owners in the project neighborhood is critical for success. Looking at this issue from the negative side, Rolon (2008) observed that when there is not public support for a special assessment district, legal opposition can endanger project success and/or increase project costs and cause delays. 
Second, implementing value capture strategies across multiple jurisdictions is especially difficult. Zhao and Larson (2011) reported that two states - Ohio and New Jersey - have policies in place to provide guidance to jurisdictions that need to share the cost of infrastructure investments. They also provided a high-profile example of cross-jurisdictional coordination failure from Virginia in which two counties were unable to both approve a funding strategy for a new rail line.

Third, local government support through land use coordination can be critical for success. The USGAO (2010) reported that some agencies successfully partner with local governments to change zoning in station areas to allow for higher density, while others struggle to implement joint development projects because the local government is unwilling to change zoning laws. Mathur and Smith (2012) found that some transit agencies operating across multiple jurisdictions will only pursue value capture funding options in those cities and counties within their service area that have supportive zoning laws.

Fourth, particularly in the case of joint development, lack of real estate expertise at the transit agency is a substantial barrier. In their survey of 55 transit agencies, the USGAO (2010) found that of those that have extensive joint development programs, most also have in-house real estate expertise. Mathur and Smith (2012) identified both transit agency institutional capacity and "[lack of] understanding of the complicated private real estate development process" (97) as barriers to joint development funding for transit.

Fifth, where the mission of the transit agency explicitly excludes land development, land value capture opportunities are limited. This is especially true in the case of joint development strategies, but it can also impact the feasibility of strategies such as special assessment districts, which can be more attractive to beneficiaries if they are partially compensated with zoning changes such as density bonuses. As Cervero et al. (2004) pointed out, the boards of some transit agencies do not believe that their agencies should be involved in real estate development. Landis, Cervero, and Hall (1991) suggested that for joint development projects, “...the agency with the lead responsibility for pursuing joint development must have an entrepreneurial bent.” (431)

Finally, multiple authors point out that value capture implementation is more likely to succeed in the context of a growing economy (e.g. USGAO 2010; Mathur and Smith 2012; Zhao and Larson 2011; Landis, Cervero, and Hall 1991). The Great Recession that began in 2008 in particular made it difficult for agencies to use value capture strategies to fund transit (USGAO 2010). The reasons for this are related to both political feasibility and the value of tax- and feebased revenue streams.

We find evidence for all of these points in our cases. We contribute to this literature by examining how transit agency institutional, political, and historical contexts affect their success in implementing location-based funding strategies. The vast majority of the existing literature is organized by strategy and project, rather than city and transit agency. It has therefore largely missed the opportunity to fully explore the role of transit agency institutional characteristics. Our work is unique, both because we look at a broad set of strategies and because our focus is on how 
transit agencies have been able to create location-based funding portfolios to help pay for their systems.

\section{CASE STUDIES}

It is not an exaggeration to say that most - if not all - sizable transit agencies have considered using value capture to help defray costs. However, as our research demonstrates, implementation is far more challenging than the literature suggests. Indeed, outside of Hong Kong and Tokyo, most cities and their transit agencies have been unable to overcome all the obstacles they face. The goal of this research was to learn the stories of how a few large transit agencies in North America and Europe fared in implementing location-based funding for transit, and synthesize lessons learned.

\section{Methods}

To fully appreciate the reported findings, it is important to understand the background for this work. This research grew out of a conversation among high-level transit agency officials from around the world. Value capture was easy for them to conceptualize, but was proving difficult to implement at a scale sufficient to create a measurable impact. They wanted to understand why location-based funding strategies had not become standard practice for transit funding - even though value capture is not a new idea and the theory behind it is obvious and sound. They wanted to learn about the challenges and opportunities faced by transit agencies that were implementing these strategies in a significant way in North American and European contexts. We were asked to investigate.

Our approach was to conduct in-depth case studies of the location value capture experiences of the major transit agencies in six North American and European cities: New York, London, Paris, Washington DC, Montreal, and San Francisco. Case selection was based on a combination of participation in the original conversation that was the genesis of the project, knowledge that each selected case agency was using or seriously considering location value capture transit funding options, and location in North America or Europe.

We conducted one in-depth phone interview with the individual(s) chiefly responsible for implementing value capture-based funding strategies for the transit agency. Interviewees were high-level agency staff, many of whom had been working at their agencies for decades. They received the questions ahead of time, and had the opportunity to review and correct interview transcripts and notes. In the interviews, we discussed current value capture initiatives, past experiences, and future agency plans. We learned details of the value capture mechanisms in use, including how much revenue these mechanisms generate, and what that revenue supports. We also learned the details of the process for adopting and implementing location value capture funding for transit in each place.

To construct full case studies, we used the interview content together with written agency documentation and other published resources that provide additional points of view. The big picture results were synthesized by the research team by identifying common themes among the case studies. The results of our work were presented at two international meetings of transit 
officials in 2014, and many attendees had been involved in the original conversation that began the work. Participants were enthusiastic about the usefulness of the work, and provided helpful comments that are incorporated into this article.

Our case study evidence is organized into two sections. The first presents our findings regarding the actual implementation of location value capture in each city, including examples of projects funded with associated funding amounts raised, as well as funding amounts raised from location value capture strategies that are not project-specific. The second presents our findings regarding the process of location value capture implementation, using examples to illustrate how this process differs by institutional context.

\section{Value capture on the ground in six cities}

Table 2 provides examples of specific large transit infrastructure projects in the case study cities that have been or will be financed partly using location value capture strategies. Four of the case study cities paid or are paying for significant new infrastructure through value capture. Montreal is likely to begin raising significant funds through location value capture mechanisms in the near future. Although San Francisco raises more than 25\% of its total budget from location value capture mechanisms, it is not included in the table because the revenue raised is not dedicated to a specific large project. Using these mechanisms for large projects is a relatively new phenomenon in all of our case study cities.

Table 2: Funds Raised for Selected Large Value Capture Projects in Case Study Cities

\begin{tabular}{|l|l|l|l|}
\hline City & $\begin{array}{l}\text { Value Capture Financed } \\
\text { Project }\end{array}$ & Funds Raised or Projected & $\begin{array}{l}\text { Percent of } \\
\text { Project Cost or } \\
\text { Budget }\end{array}$ \\
\hline London & Crossrail & $\begin{array}{l}£ 4.1 \text { billion (Business Rate Supplement) } \\
£ 0.6 \text { billion* (Community Infrastructure Levy) }\end{array}$ & $32 \%$ \\
\hline Paris & Grand Paris Express & $€ 21.8$ billion* & $80 \%$ \\
\hline Washington & $\begin{array}{l}\text { New York Avenue Metro } \\
\text { Station (2001) }\end{array}$ & $\$ 25$ million & $28 \%$ \\
\hline Washington & $\begin{array}{l}\text { Dulles Metrorail Silver } \\
\text { Line Expansion }\end{array}$ & $\begin{array}{l}\$ 400 \text { million (Tyson’s Corner SAD) } \\
\$ 330 \text { million (Reston/Herndon SAD) }\end{array}$ & $14 \%$ \\
\hline New York & Subway 7 Line Extension & $\$ 2.37$ billion (Hudson Yards TIF-like) & $98 \%$ \\
\hline
\end{tabular}

$\mathrm{SAD}=$ Special Assessment District; TIF = Tax Increment Financing.

* There is some indication that actual funding may fall short of these projected levels.

Table 3 provides an overall look at which mechanisms are in use in each of the case study cities. There are two points of note. First, all cities are implementing at least two mechanisms on this list, and a number are implementing most of them. Second, in all cases except Montreal, revenues that capture location value are significant. Transport for London estimated that location value capture revenues cover approximately $10 \%$ of total system costs. The payroll taxes in Paris and New York cover $40 \%$ of operating costs and $10 \%$ of system costs, respectively, and each of 
these cities has other important sources of location-based revenue as well. The San Francisco Municipal Transportation Agency raises 25\% of their transit operating costs from parking fees, and a transportation tax on new development was passed in late 2015 (San Francisco Planning Code 2016). In coordination with local business interests, the Washington Metropolitan Area Transit Authority has raised a substantial portion of the capital costs for two infrastructure projects using special assessment districts.

Table 3: Value Capture Mechanisms in Case Study Cities

\begin{tabular}{|l|c|c|c|c|c|c|}
\hline & London & Paris & $\begin{array}{l}\text { Wash. } \\
\text { DC }\end{array}$ & $\begin{array}{l}\text { New } \\
\text { York }\end{array}$ & Montreal & San Francisco \\
\hline $\begin{array}{l}\text { Land value tax/Location } \\
\text { benefit levy }\end{array}$ & $\mathbf{X}$ & & & & & \\
\hline $\begin{array}{l}\text { Tax Increment Financing } \\
\text { (TIF) }\end{array}$ & $\mathbf{X}$ & & & $\mathbf{X}$ & & $\mathbf{X}$ \\
\hline Joint development & $\mathbf{X}$ & $\mathbf{X}$ & $\mathbf{X}$ & $\mathbf{X}$ & & $\mathbf{X}$ \\
\hline Sale or lease of land & $\mathbf{X}$ & & & $\mathbf{X}$ & & $\mathbf{X}$ \\
\hline $\begin{array}{l}\text { Sale or lease of development } \\
\text { rights or air rights }\end{array}$ & $\mathbf{X}$ & $\mathbf{X}$ & $\mathbf{X}$ & $\mathbf{X}$ & $\mathbf{X}$ & $\mathbf{X}$ \\
\hline $\begin{array}{l}\text { Advertising and lease of } \\
\text { commercial space in stations }\end{array}$ & & $\mathbf{X}$ & & $\mathbf{X}$ & & $\mathbf{X}$ \\
\hline Motorist fees & $\mathbf{X}$ & $\mathbf{X}$ & & $\mathbf{X}$ & & $\mathbf{X}$ \\
\hline Payroll-based tax & & & & $\mathbf{X}$ & & \\
\hline $\begin{array}{l}\text { Transit-focused development } \\
\text { fees }\end{array}$ & & & $\mathbf{X}$ & & \\
\hline $\begin{array}{l}\text { Transit-focused property } \\
\text { transaction taxes }\end{array}$ & & & & & \\
\hline Special assessment districts & & & & & \\
\hline
\end{tabular}

Location value capture without institutional change: New York City and Washington, DC

The New York Metropolitan Transportation Authority (MTA) and the Washington Metropolitan Area Transit Authority (WMATA) are two of the largest US transit agencies, respectively serving 2.7 billion and 300 million trips annually. They service two of the nation's strongest urban real estate markets. Both markets respond positively to improved rail transit service, and location-based funding is a promising source of revenue. Yet both agencies have struggled to leverage this advantage.

Their common problem is political complexity borne of misalignment between institutional governance and economic regions served. In each case, the transit service region transcends critical political boundaries. The MTA, a creature of New York State, serves New 
York City and its suburban counties to the north and east. New York State, governed from Albany, a few hours' drive away, has substantial representation from outside the service region and does not necessarily share Metropolitan New York's priorities. There are also substantial conflicting interests between residents of New York City proper and suburban residents. Such geographic differences spill over into policy-making areas such as approaches to location value capture mechanisms. Speaking generally about the challenge of using these mechanisms to pay for a significant fraction of the transit budget, an interviewee from MTA commented, "It's an ongoing struggle. Nobody wants to pay more taxes, and one-off value capture projects will never do it.”

The District of Columbia, the State of Maryland, and five cities and counties within the Commonwealth of Virginia jointly created WMATA. It receives subsidies from each of these governments for operations and capital expenses. This institutional structure protects the agency from budgetary crisis; if the agency had a major financial crisis, then its member governments would be responsible to raise funds to solve it. However, fragmentation also makes it virtually impossible for WMATA to implement large-scale, coordinated, system-wide location value capture programs because the legal frameworks for taxation are substantially different in each jurisdiction. As one interviewee at WMATA put it, large-scale location value capture is "a very attractive yet very impossible way to generate funding” (2014).

Despite these institutional constraints, location value capture strategies provide funding for both WMATA and MTA. WMATA has an active joint development program ${ }^{1}$, and has been the recipient of Special Assessment District (SAD) funding from three separate SADs to help pay for two expansion projects (see Table 3). A key component that led to the success of the SAD funding was the support of the local business community (Rybeck 2004; Duggan 2014). WMATA's experience illustrates that project-specific local funding - especially when championed and paid for by the business community - can help pay for critical new transit infrastructure even when the agency institutional structure does not support systemwide location value capture strategies.

The MTA's value capture narrative is largely one of creative funding mechanisms that evolved in response to ongoing fiscal shortfalls. Its current funding base includes three locationbased revenue streams that cover a substantial fraction of the agency's expenditures: transfer taxes on real estate sold within the city limits, a region-wide payroll tax, and bridge and tunnel toll revenue. The payroll tax was implemented in 2009 in response to a severe budget crisis at the MTA. The tax raises $\$ 1.2$ billion annually for the agency, and is especially controversial. Multiple lawsuits have been brought against the MTA attempting to eliminate it, but the tax remains in force.

In addition, the agency works with developers to obtain station and station-area enhancements (Suzuki et al. 2015), and recently negotiated real estate deals for two large MTA properties (Atlantic and Hudson Yards). Joint development can be lucrative in New York - a recent project adjacent to Grand Central station agreed to pay more than \$200 million for station enhancements in exchange for the right to build a taller building (Sclar, 2016). 
Revenue from a tax increment financing (TIF)-like strategy for the Hudson Yards redevelopment is paying more than $\$ 2$ billion for the construction of an extension to the MTA's Subway Line 7. This example represents an extreme case of TIF where the baseline value was set at zero, meaning that all of the property tax proceeds from the area go to pay for local infrastructure. Some observers have been critical of this approach, both initially (Cerciello 2004; NYCIBO 2004) and when tax revenues fell short of expectations in 2013 (NYCIBO 2013; Fisher 2015). It is not yet clear whether it will be a net financial gain or loss for both the MTA and New York City (NYICBO 2004; NYICBO 2013).

\section{Institutional entrepreneurs: London, San Francisco, Paris, and Montreal}

Like New York and Washington, transit agencies in London, San Francisco, Paris, and Montreal serve large numbers of riders each day, and real estate markets in these cities respond positively to transit investments. In contrast to the structural institutional rigidities in New York and Washington, the agencies in these cities are actively working to invent (in the case of the new Société du Grand Paris) or reinvent themselves in ways that facilitate location-based funding strategies across political boundaries.

Institutional reform is difficult, and it is especially difficult in large institutions such as transit agencies. Crisis is often a catalyst for reform, and an acute current or expected crisis is part of the narrative in each of these cases. These four agencies provide examples of three types of institutional change, each of which enables different location value capture strategies.

\section{New regional governments}

London and Paris have both created entirely new regional governmental bodies with the overarching goal of better integration for their regional economies. The Greater London Authority (GLA) was created in 2000, with a directly elected Mayor and the regional transport agency - Transport for London (TfL) - reporting directly to that leader. Created in 2010, the Société du Grand Paris (SGP) is supported by a dedicated set of new taxes, and a central part of its mission is to build an entirely new $200 \mathrm{~km}$ regional rail system. The new government with jurisdiction over the Greater Paris region was created to better align land use, transportation, and economic planning in the region. A newly-implemented development tax on office space is projected to raise $€ 350$ million per year, paying for a substantial portion of the construction of the new rail system.

\section{Transit agencies becoming transportation agencies}

Both San Francisco’s Municipal Transportation Authority (SFMTA) and London’s TfL have transformed themselves from transit agencies into transportation agencies. A referendum vote created the SFMTA in 1999 by merging the city's then separate Muni transit agency with their Department of Parking and Traffic. In London, the creation of TfL accomplished the same thing. In both cities, budgetary and/or operational crises in previous transit agencies led to the institutional change. In addition to the transit systems in their respective cities, they are 
responsible for the streets, bicycle routes, pedestrian infrastructure, and public parking facilities. TfL is the agency behind the city's famous congestion charge program as well.

Both of these agencies have broad transport planning and finance authority. The advantage of having a city's transportation system managed by a single agency is clear, but most cities are not organized this way. As an SFMTA interviewee said, "We're an experiment. Can you manage the right of way in a congested city?” Because the agencies control both the transit system and the roads, transit in these cities can capture part of the location value of central destinations by charging cars for driving and parking.

Montreal is following quickly in the footsteps of London and San Francisco. The Québec provincial government adopted a law in May 2016 that will eliminate the current transit governance and operations system in the city, and replace it with a regional agency that - like London's TfL and San Francisco’s MTA - will have broad transport planning and finance authority (National Assembly 2016). Montreal's institutional reform moved fast; when we conducted interviews for this research in 2014, officials were then just beginning to seriously consider major reform by studying the institutional structures in both London and Vancouver, BC.

It is worth noting that New York's MTA is also more than just a transit agency - it has authority over a number of the city's bridges and tunnels as well, and bridge and tunnel tolls do provide some funding for transit. However, the MTA does not have full broad authority over the region's - or even the City's - transport system.

\section{Tax-based location value capture through governmental partnerships}

All of our case study agencies partner with city, county, state/provincial, and national governments to implement tax-based location value capture strategies - or they are trying to do so. The difference between the entrepreneurial agencies and WMATA/MTA is that WMATA and MTA partner when the local governments or tax-paying stakeholders are the champions of that partnership. In contrast, interviewees from London, Montreal, and San Francisco all reported that they are actively seeking to change the legal framework in specific ways so that using taxbased location value capture to fund transit is the norm rather than the exception.

In London, two new taxes provide substantial funding for the Crossrail line that will soon traverse the region. The Business Rates Supplement (BRS) is an add-on to an existing property tax on commercial buildings, and the Community Infrastructure Levy is a tax on new development that is spatially graduated according to the property's proximity to the new line. Both taxes required and obtained approval from the UK national government.

The BRS in particular is raising a large sum of money to pay for the Crossrail project, and there has been "remarkably little fuss" (TfL interviewee 2014) about it. The reason is likely two-fold. First, most of the businesses in London that are close to the route expect the value of their buildings to go up by $10-15 \%$ as a direct result of the Crossrail. The BRS is lower than that, so they can easily see that they will profit overall. Second, the Crossrail project has a 20-year history as an often-discussed strategy to relieve the congestion on the existing transport system in central London. An interviewee from TfL explained that when the time came to actually 
implement the BRS and the project, "the general feeling from the population was kind of 'get on with it." ' Looking forward, TfL is working to convince the national government that all of the business rates paid in London should be devolved to the regional and local governments that provide services to the Greater London area.

Although Montreal has not yet funded major infrastructure using location value capture mechanisms, a significant project is currently underway. Historically, the Québec provincial government has financed $100 \%$ of rail expansions but only $75 \%$ of the cost of most other local infrastructure projects. This system clearly incentivizes local jurisdictions to request rail over other transport investments, and the Québec government has recently changed this policy. Because rail is expensive, local jurisdictions need new ways to raise revenue for their share of new rail projects. The Montreal region's current transit agency - Agence Métropolitaine de Transport (AMT) - actively pursued location-based funding as a way forward. First, AMT sponsored a study to verify that proximity to commuter rail in the Montreal region adds value to properties (Dubé et al. 2013). Then, AMT submitted a formal request to Québec to suggest the use of location-based strategies to fund rail expansion in the region. In 2015, the Québec National Assembly approved a new model for infrastructure projects, whereby the province's pension fund investment agency (Caisse de dépôt et placement du Québec) is officially authorized to execute infrastructure projects (National Assembly 2015). The first project that the agency is involved in will build a new 67 kilometer, $\$ 5.9$ billion light rail line in the Montreal region, with part of the funding coming from real estate development along the line (Smith 2016; Madger 2016).

In late 2015, San Francisco replaced the city’s longstanding Transit Impact Development Fee with a holistic Transportation Sustainability Fee that will raise substantially more revenue. This change both raises the fee for commercial development and extends the current nonresidential development fee to apply to market rate residential development as well. The proposal was years in the making, and represents a partnership between the Mayor's office, the city Planning Department, and the SFMTA. As such, a news report leading up to the policy change included the heading “No outright opposition.” (Dineen and Cabanatuan 2015)

\section{LESSONS FROM SIX CITIES}

Each individual case is at once unique in time and place and yet reflective of similar forces and pressures at work in the other sites. Effectively using location-based mechanisms as part of a transit funding plan requires that practitioners understand the immediate political and institutional challenge they face. The question is not whether it can work; the literature is clear on conditions for that. The relevant question is a "how" question. How can my transit agency implement location value capture effectively and equitably given the local situation? Our case data uncovered some repetitive key themes.

\section{"You never want a serious crisis to go to waste."”}

One of the most powerful facts to emerge from our six cases is the role of crisis in creating opportunity. In five out of six case study cities, an acute current or expected funding or 
operational crisis induced the transit agency to seek new alternatives, and became a catalyst for location value capture implementation. However, this was not universal. Use of location value capture in Washington DC was part of an ongoing process of change.

While this observation about the role of crisis is true for the systems we investigated, the cases of Hong Kong and Tokyo demonstrate that transport systems can be built from the start on a location-based funding platform, integrating land and transit development (Cervero and Murakami 2009; Murakami 2012; Calimente 2012; Suzuki et al. 2015).

\section{Public support}

A second theme highlights the importance of support from both the public and from all levels of government. For location-based funding strategies to be successful, the public must either accept new taxes or approve the reallocation of existing taxes. Is the public willing to accept any new taxes?

In places where the status quo has been for the state, provincial, or national government to pick up the tab, the public does not easily accept new taxes. An interviewee from WMATA spelled this out clearly, saying, “This is Washington. Everybody likes to point the finger at Capitol Hill and beg for money. I think that ends up being the default position.”

Another important question is who is paying these taxes: Households? Businesses? Developers? Motorists? Our case study cities were implementing value capture strategies in which the latter three of these groups pay. This is in spite of the fact that in many cities, much of the benefit value accrues in asset appreciation of residential properties. The reason, of course, is that there are equity concerns about taxing a non-liquid asset and an associated lack of political support for such policies. An interviewee from Transport for London said, “An Englishman’s home is his castle,” explaining that residential properties in the United Kingdom receive favorable terms across many sorts of taxes. Suggesting increasing the property tax on residences is a political nonstarter. In contrast, there can be surprisingly little controversy over new taxes that target businesses, developers, and motorists.

\section{Transit Agency Governance}

Our most illuminating findings relate to transit agencies as governance institutions. Two organizational aspects stand out as important for value capture facilitation: institutional readiness and institutional willingness. We consider each.

\section{Institutional readiness: Authority}

In order to capture the value of locations, at least one of the following must be true about the transit agency or company:

1. It has the authority to tax those who benefit.

2. It works in close collaboration with the taxing authority.

3. It owns the land that increases in value, and is therefore the direct location value beneficiary. 
To maximize the location value, it is also helpful for the transit agency or company to be closely aligned with those who make decisions about local transport and land use planning.

Where location value capture strategies are a central part of transit funding, basic institutional arrangements are critical. In the Hong Kong and Tokyo cases, the transit companies are the direct location value beneficiaries and the cities have coordinated transport and land use policies to incentivize and facilitate transit use (Cervero and Murakami 2009). None of the transit agencies in our six case study regions are in this situation. However, four of them have recently and intentionally undergone major institutional reform, improving their ability to implement location value capture strategies.

\section{Institutional willingness: The entrepreneurial transit agency}

It is important to appreciate the power of organizational mission in guiding agency behavior. Many transit agencies view their mission narrowly, as one of making the trains and buses run safely and reliably. In these cases, agency leaders take the budget, technology, system extent, and workforce as given. Within these constraints they do the best they can to move large numbers of riders on a daily basis. System funding is seen as the responsibility of the government above them. Employees (and even leaders) of transit agencies that do not have an internalized mission broader than service operation have little incentive to think "outside the box" to increase system funding.

As is clear from our case study evidence, some agencies have recently begun taking a broader view of themselves and their mission. They actively seek ways to increase budgets; adapt routes, schedules, and technology to serve current and future riders better; to improve their workforce; and to enhance the regional economy.

These differences in mission translate into differences in the ways that agencies view opportunities. For instance, in response to a question about commercial leasing of space in stations, an interviewee from the Washington Metropolitan Area Transit Authority explained, “Our spaces are used to move passengers, and we don't have a lot of excess [space].” In contrast, an interviewee from Montreal's Agence Métropolitaine de Transport reported that all transit providers in that city are working to increase their non-fare revenue sources, and they aim to lease commercial space in their stations wherever it will be profitable to do so.

This discussion begs the question: What determines whether a transit agency has a broad or narrow view of their mission? We cannot definitively answer that from our data. However, we can infer from the tenor of our interviews that much of the explanation likely hearkens back to the ways in which the current mission of each agency evolved.

While public value capture is a relatively new idea, private value capture from transit provision is as old as the service itself. In both Europe (McKay 1976; Wolmar 2004; Millward 2005) and the United States (Mason 1932; Warner 1962; Schaeffer and Sclar 1975; Edel, Sclar, and Luria 1984; Hood 1993), transit entrepreneurs well understood that the real capital gain from transit production was in location value creation, in the construction contracts, and, only in rare instances, from the density of usage. Once the entrepreneurs captured the locational gain and paid off the construction contracts, the costs of system operation were not worth the farebox 
benefits. Because public transport is a vital urban public service, government could not allow it to disappear. The public transit agencies that emerged in Europe and North America in reaction to these private decisions were not initially organized around a mission requiring more than trying to make ends meet through farebox revenues, if possible. If they failed, the government bailed them out using general tax revenues. That is the basic culture from which these publicly operated transit systems initially sprung; that is the DNA we found in our research.

The examples in our case studies of agencies that recently transformed themselves to broaden their authority and reframe their missions demonstrate that such change is possible. San Francisco, London, Paris, and Montreal are all actively working to change their organizational mission and institutional structure. In each case, the intention is to give the agencies more flexibility and to encourage them to become more entrepreneurial public transit providers. These tendencies are not the norm. We specifically chose these cases because they were experimenting with, using, or actively contemplating location-based funding strategies. In that regard, these are among the most entrepreneurial agencies. But the fact that they are successfully making big changes to their institutional structures is huge. In light of this, it is important to view public transport agencies as not rigid structures, but instead as institutions that can transform in response to changing situations.

\section{CONCLUSION}

This article presents findings from in-depth organization-focused case studies of the use of location value capture strategies to fund transit in four North American and two European cities. Although there is substantial diversity among these cases, we have identified what we believe are key commonalities that illuminate how and why some cities and their transit agencies have been especially successful in implementing location value capture.

We make two new contributions to the literature. We first posit that the concept of location value capture is a useful practical extension of the well-known concept of land value capture. We argue that the increased value of location can manifest in many ways in the urban economy, including land value increases, business revenues, developer profits, advertiser value, and labor market improvements. It follows logically, then, that if public investments increase location value, the public sector might reasonably aim to capture a portion of the location value increase by targeting any of these manifestations of value. There is no particular reason to limit this concept to capturing the increased value of land; in practice, the public sector implements location value capture in a multitude of ways.

Second, we focus not on specific projects that used value capture-based funding, but instead on transit agency success in incorporating location value capture strategies into their overall budgets. This holistic lens illuminated striking institutional differences between the agencies we studied that substantially affected success in this realm. Specifically, we saw clearly that implementing location value capture strategies was more challenging for agencies that did not have a supportive institutional structure and organizational mission in place.

It was especially remarkable that four of the six agencies we studied had undergone or are in the process of radical institutional reform, changing their institutional authority as well as 
altering their organizational missions. To be clear, institutional reform was not one of the criteria used to select cases. It became evident, however, that these reforms were critical enablers of location value capture implementation. In our interviews, officials in London, San Francisco, Paris, and Montreal were decidedly upbeat about prospects for future use of value capture as a transit funding mechanism because their institutional structure was supportive. In contrast, while officials in Washington DC and New York were upbeat about prospects for project-based value capture funding, they were pessimistic about systemic institutional support for other types of location value capture funding.

Some might interpret our results to mean that funding transit using location value capture mechanisms is extraordinarily challenging, practically requiring wholesale reinventing of the transit agency institution. We take a more sanguine view. We see an evolutionary institutional process at work. Transport governance changes in response to pressures generated by larger imperatives of economy and environment. But institutional change in any individual agency is either hampered or facilitated by the path dependent process of its creation and subsequent evolution. The importance of studies such as this are that they provide ideas and alternatives to decision makers about ways to facilitate improved change processes in their organizations.

However, it is also important to note that the results presented and discussed here are based on a small and somewhat self-selected sample of only six transit agencies, all of which are located in large, dense, "transit legacy" cities. Thus, this work may be seen as the beginning of what we believe should become a new thread in the literature.

To test the generalizability of the findings presented here, additional research is needed. This work could include a more systematic study of the relationship between institutional structure and location value capture funding for transit in a much larger number of transit agencies, a study that focuses on the process of transit agency institutional reform itself, or comparative work that investigates location value capture in the context of other government agencies.

\section{NOTES}

${ }^{1}$ WMATA's joint development program has been the subject of much study (e.g. Cervero, Hall, and Landis 1990; Cervero et al. 2004; Mathur and Smith, 2013; Suzuki et al. 2015). Although the agency has been a leader in including joint development as a visible part of their budget, and they have dedicated staff who specialize in joint development, we do not emphasize it here because it does not actually generate a lot of funding. Summarizing their findings on the contributions of joint development to the budgets of WMATA and three other major US transit agencies, Cervero et al. (1990) wrote, “Clearly, capital contributions from joint development have played a miniscule role in the capital finance budgets of these four transit agencies, all among the nation’s largest.” (p.158) This fact has not changed (GAO 2010 provides an update), and was repeated in our 2014 interview of WMATA staff, who were unenthusiastic about the potential for substantial joint development-based funding for their system. 
2 "You never want a serious crisis to go to waste. And what I mean by that is an opportunity to do things that you think you could not do before." Rahm Emanuel, as chief of staff for presidentelect Barack Obama. Speaking to the Wall Street Journal CEO Council, Nov 19, 2008. https://www.youtube.com/watch?v=_mzcbXi1Tkk

\section{ACKNOWLEDGEMENTS}

This work is based on a paper originally commissioned by the Regional Plan Association for the Transit Leadership Summit (www.transitleadership.org) and was made possible by funding from the Volvo Research and Education Foundation. We thank the staff involved in the transit business in six case study cities who volunteered their time to candidly share their experience in considering and implementing value capture mechanisms, as well as those who participated in workshops where the findings were presented. The paper also benefitted from useful suggestions from both journal editors and multiple external reviewers, and we thank them. Any and all errors are, of course, the responsibility of the authors.

\section{REFERENCES}

American Public Transit Association (APTA). 2015. Value Capture for Public Transportation Projects: Examples. https://www.apta.com/resources/reportsandpublications/Documents/APTAValue-Capture-2015.pdf

Arnott, Richard and Joseph Stiglitz. 1979. Aggregate Land Rents, Expenditure on Public Goods and Optimal City Size. The Quarterly Journal of Economics, Vol. XCII, No. 4 November 471500.

Board of Trade of Metropolitan Montreal (BTMM). 2004. Public transit: a powerful economicdevelopment engine for the metropolitan Montreal region. http://www.ccmm.qc.ca/documents/memoires/2004_2005/BTMM_PublicTransit_study.pdf Calimente, John. 2012. Rail integrated communities in Tokyo. The Journal of Transport and Land Use 5(1): 19-32. DOI: http://dx.doi.org/10.5198/jtlu.v5i1.280

Cerciello, Amy F. 2004. Use of Pilot Financing to Develop Manhattan's Far West Side. Fordham Urban Law Journal 32(5): 101-136. http://ir.lawnet.fordham.edu/ulj/vol32/iss5/1

Cervero, Robert, Peter Hall, and John Landis. 1990. Transit Joint Development in the United States. Monograph 42, Institute of Urban \& Regional Development, University of California at Berkeley. Retrieved from http://escholarship.org/uc/item/07t5930g\#page-2

Cervero, Robert and Jin Murakami. 2009. Rail and property development in Hong Kong: experiences and extensions. Urban Studies 46(10): 2019-2043. DOI:

10.1177/0042098009339431 
Cervero, Robert, Steven Murphy, Christopher Ferrell, Natasha Goguts, Yu-Hsin Tsai, G.B. Arrington, John Boroski, Janet Smith-Heimer, Ron Golem, Paul Peninger, Eric Nakajima, Ener Chui, Robert Dunphy, Mel Myers, Shannon McKay, and Nicole Witenstein. 2004. TransitOriented Development in the United States: Experiences, Challenges, and Prospects. Transit Cooperative Research Program (TCRP) Report 102, Washington, DC: Transportation Research Board. http://onlinepubs.trb.org/onlinepubs/tcrp/tcrp_rpt_102.pdf

Cornia, Gary C. and Ray D. Nelson. 2010. State tax revenue growth and volatility. Federal Reserve Bank of St. Louis Regional Economic Development 6(1): 23-58.

Dineen, J.K. and Michael Cabanatuan. 2015. City proposing new housing development fee to expand transit. San Francisco Chronicle, July 21.

Dubé, Jean, Marius Thériault, and François Des Rosiers. 2013. Commuter rail accessibility and house values: The case of the Montreal South Shore, Canada, 1992-2009. Transportation Research Part A: Policy and Practice 54: 49-66. DOI:10.1016/j.tra.2013.07.015

Debrezion, Ghebreegziabiher, Eric Pels, and Piet Rietveld. 2007. The impact of railway stations on residential and commercial property value: A meta-analysis. Journal of Real Estate Finance and Economics 35(2): 161-180. DOI: 10.1007/s11146-007-9032-z

Duggan, Paul. 2014. The Silver Line story: A new route is born after decades of faulty planning, political paralysis. The Washington Post, June 23.

Edel, Matthew, Elliott Sclar and Daniel Luria. 1984. Shaky Palaces: Homeownership and Social Mobility in Boston's Suburbanization, New York: Columbia University Press.

Fisher, Bridget. 2015. The Myth of Self-Financing: The Trade-Offs Behind the Hudson Yards Redevelopment Project. Schwartz Center for Economic Policy Analysis and Department of Economics, The New School for Social Research, Working Paper Series 2015-4.

http://www.economicpolicyresearch.org/images/docs/research/political_economy/Bridget_Fisher _WP_2015-4_final.pdf

GVA, Ltd. 2012. Crossrail property impact study. Prepared by GVA for Crossrail, Ltd. http://www.crossrail.co.uk/route/property-developments-and-urban-realm/propertydevelopments/

Hood, Clifton. 1993. 722 Miles: The Building of the Subways and how they transformed New York. Baltimore: Johns Hopkins University Press.

Iacono, Michael, David Levinson, Zhirong Jerry Zhao, and Adeel Lari. 2009. Value capture for transportation finance: Report to the Minnesota Legislature. Report No. CTS 09-18S. http://www.cts.umn.edu/Research/featured/valuecapture/ 
Ingram, Gregory K. and Yu-Hung Hong. 2012. Land Value Capture: Types and Outcomes. In: Ingram, Gregory K., and Yu-Hung Hong (Eds.). Value capture and land policies. Lincoln Institute of Land Policy.

Jérôme, Béatrice. 2014. Grand Paris: le financement du futur métro menacé. Le Monde, February 2. http://www.lemonde.fr/politique/article/2014/02/06/grand-paris-le-financement-du-futurmetro-menace_4360991_823448.html

Landis, John, Robert Cervero, and Peter Hall. 1991. Transit joint development in the USA: an inventory and policy assessment. Environment and Planning C: Government and Policy 9(4): 431-452.

Lari, Adeel, David Levinson, Zhirong Jerry Zhao, Michael Iacono, Sarah Aultman, Kirti V. Das, Jason Junge, Kerstin Larson, and Michael Scharenbroich. 2009. Value capture for transportation finance: Technical research report. Report no. CTS 09-18. University of Minnesota Center for Transportation Studies. http://www.cts.umn.edu/Publications/ResearchReports/reportdetail.html?id=1802

Madger, Jason. 2016. Caisse's REM light-rail project: 3 stations added to proposed route. Montreal Gazette, November 25. http://montrealgazette.com/news/local-news/three-rem-trainstations-added-to-proposed-route-through-downtown-montreal

Mason, Edward. 1932. The Street Railway in Massachusetts: The Rise and Decline of an Industry. Cambridge: Harvard University Press.

Mathur, Shishir, and Adam Smith. 2012. A Decision-Support Framework for Using Value Capture to Fund Public Transit: Lessons From Project-Specific Analyses, Research Report 1114, Mineta Transportation Institute Publications. http://scholarworks.sjsu.edu/cgi/viewcontent.cgi?article=1014\&context=urban_plan_pub

Mathur, Shishir, and Adam Smith. 2013. Land value capture to fund public transportation infrastructure: Examination of joint development projects' revenue yield and stability. Transport Policy 30: 327-335. DOI:10.1016/j.tranpol.2013.09.016

McKay, John P. 1976. Tramways and Trolleys: The Rise of Urban Mass Transport in Europe. Princeton NJ: Princeton University Press.

Millward, Richard. 2005. Public and Private Enterprise in Europe: Energy, Telecommunications and Transport, 1830-1990. Cambridge UK: Cambridge University Press

Mohammad, Sara I., Daniel J. Graham, Patricia C. Melo, and Richard J. Anderson. 2013. A meta-analysis of the impact of rail projects on land and property values. Transportation Research Part A: Policy and Practice 50: 158-170. DOI: 10.1016/j.tra.2013.01.013. 
Murakami, Jin. 2012. Transit Value Capture: New Town Codevelopment Models and Land Market Updates in Tokyo and Hong Kong. In: Ingram, Gregory K. and Yu-Hung Hong (Eds.). Value capture and land policies. Lincoln Institute of Land Policy.

National Assembly. 2015. Bill 38 (2015, chapter 17) An Act to allow the Caisse de dépôt et placement du Québec to carry out infrastructure projects.

http://www2.publicationsduquebec.gouv.qc.ca/dynamicSearch/telecharge.php?type=5\&file=201 5C17A.PDF

National Assembly. 2016. Bill 76 (2016, chapter 8) An Act to modify mainly the organization and governance of shared transportation in the Montréal metropolitan area.

http://www2.publicationsduquebec.gouv.qc.ca/dynamicSearch/telecharge.php?type=5\&file=201 6C8A.PDF

New York City Independent Budget Office (NYCIBO). 2004. West Side Financing's Complex, \$1.3 Billion Story. Fiscal Brief. http://www.ibo.nyc.ny.us/iboreports/WestsidefinanceFB.pdf

New York City Independent Budget Office (NYCIBO). 2013. Financing Redevelopment on the Far West Side: City's Spending on Hudson Yards Project Has Exceeded Initial Estimates. Fiscal Brief. http://www.ibo.nyc.ny.us/iboreports/hudsonyards2013.html

Pack, Janet R. 1992. You ride, I'll pay: social benefits and transit subsidies. The Brookings Review 10(3): 48-51. DOI: 10.2307/20080319

Peterson, George E. 2009. Unlocking land values to finance urban infrastructure. Washington, DC: The World Bank.

Rolon, Abigail. 2008. Evaluation of value capture mechanisms from linkage capture to special assessment districts. Transportation Research Record: Journal of the Transportation Research Board, 2079: 127-135. DOI: 10.3141/2079-16

Royal Institute of Chartered Surveyors Policy Unit (RICS). 2002. Land Value and Public Transit. Office of the Deputy Prime Minister, London, UK.

Rybeck, Rick. 2004. Using value capture to finance infrastructure and encourage compact development. Public Works and Management Policy 8(4): 249-260. DOI:

$10.1177 / 1087724 X 03262828$

Salon, Deborah, and Sharon Shewmake. 2011. Opportunities for value capture to fund public transport: A comprehensive review of the literature with a focus on East Asia. http://papers.ssrn.com/sol3/papers.cfm?abstract_id=1753302

San Francisco Planning Code. 2016. Section 411A Transportation Sustainability Fee. http://library.amlegal.com/nxt/gateway.dll/California/planning/article4developmentimpactfeesan dprojectr?f=templates\$fn=default.htm\$3.0\$vid=amlegal:sanfrancisco_ca\$anc=JD_411A 
Schaeffer, K.H. and Elliott Sclar. 1975. Access for All: transportation and urban growth. Harmondsworth Middlesex UK: Penguin Books.

Sclar, Elliott. 2016. Castles in the air: Transferable development rights and the privatization of zoning in New York City. Paper presented at the Association of Collegiate Schools of Planning Annual Meeting, Portland, Oregon November 2016.

Smith, Jeffrey J. and Thomas A. Gihring. 2006. Financing transit systems through value capture. American Journal of Economics and Sociology 65(3): 751-786. DOI: 10.1111/j.15367150.2006.00474.x

Smith, Kevin. 2016. Montreal embraces public-public infrastructure. International Railway Journal. August 17. http://www.railjournal.com/index.php/north-america/montreal-embracespublic-public-infrastructure.html

Suzuki, Hiroaki, Jin Murakami, Yu-Hung Hong, and Beth Tamayose. 2015. Financing transitoriented development with land values: Adapting land value capture in developing countries. Urban development series. Washington, DC: World Bank Group. http://documents.worldbank.org/curated/en/2014/01/20351542/financing-transit-orienteddevelopment-land-values-adapting-land-value-capture-developing-countries-overview

U. S. Government Accountability Office (USGAO). 2010. Public Transportation: Federal Role in Value Capture Strategies for Transit Is Limited, but Additional Guidance Could Help Clarify Policies. http://www.gao.gov/new.items/d10781.pdf

Warner, Sam Bass. 1962. Streetcar Suburbs: The Process of Growth in Boston (1870-1900). Cambridge: Harvard University Press.

Washington Metropolitan Area Transit Authority (WMATA). 2011. Making the Case for Transit: WMATA Regional Benefits of Transit Technical Report.

http://www.wmata.com/pdfs/planning/WMATA\%20Making\%20the\%20Case\%20for\%20Transit \%20Final\%20Tech\%20Report.pdf

Wolmar, Christian. 2004. The Subterranean Railway: How the London Underground was built and how it changed the city forever. London: Atlantic Books.

Zhao, Zhirong Jerry and Kerstin Larson. 2010. Special Assessments as a Value Capture Strategy for Public Transit Finance. Public Works Management and Policy 16(4): 320-340. DOI: 10.1177/1087724X11408923

Zhao, Zhirong Jerry, Michael Iacono, Adeel Lari, and David Levinson. 2012. Value capture for transportation finance. Procedia-Social and Behavioral Sciences 48: 435-448.

DOI:10.1016/j.sbspro.2012.06.1023 


\section{AUTHOR BIOGRAPHIES}

Deborah Salon is assistant professor in the School of Geographical Sciences and Urban Planning at Arizona State University.

Elliott Sclar is emeritus professor of urban planning at Columbia University where he directs the Center for Sustainable Urban Development at the University’s Earth Institute.

Richard Barone is the Regional Plan Association's director of transportation programs. 